University of Nebraska - Lincoln

DigitalCommons@University of Nebraska - Lincoln

Irrigation Technology Transitions in the Mid-plains States: Implications for Water Conservation/Water Quality Goals and Institutional Changes

\author{
Glenn D. Schaible \\ Resource Economics Division, Economic Research Service, United States Department of Agriculture, \\ Schaible@ers.usda.gov \\ Marcel P. Aillery \\ Resource Economics Division, Economic Research Service, United States Department of Agriculture
}

Follow this and additional works at: https://digitalcommons.unl.edu/usdaarsfacpub

Schaible, Glenn D. and Aillery, Marcel P., "Irrigation Technology Transitions in the Mid-plains States: Implications for Water Conservation/Water Quality Goals and Institutional Changes" (2003). Publications from USDA-ARS / UNL Faculty. 1544.

https://digitalcommons.unl.edu/usdaarsfacpub/1544

This Article is brought to you for free and open access by the U.S. Department of Agriculture: Agricultural Research Service, Lincoln, Nebraska at DigitalCommons@University of Nebraska - Lincoln. It has been accepted for inclusion in Publications from USDA-ARS / UNL Faculty by an authorized administrator of DigitalCommons@University of Nebraska - Lincoln. 


\title{
Irrigation Technology Transitions in the Mid-plains States: Implications for Water Conservation/Water Quality Goals and Institutional Changes
}

\author{
GLENN D. SCHAIBLE \& MARCEL P. AILLERY
}

Resource Economics Division, Suite S4050, Economic Research Service, US Department of Agriculture, 1800 M Street, NW, Washington, DC 20036-5831, USA.

Email: schaible@ers.usda.gov

ABSTRACT A Parks modified multinomial logit model is used to examine the influence of the agricultural economic environment on irrigation technology transitions in the mid-plains states. Simulation analyses assess expected agricultural water conservation and its implications for water quality/environmental goals and water institutional reform. Under baseline agri-economic assumptions, regional agricultural water use efficiency could improve from $2.3 \%$ to $9.8 \%$. Technology-specific elasticities show that crop price effects on irrigation technology transitions are relatively inelastic. Results for the mid-plains states differ from those obtained for the Pacific north-west (an earlier study), implying that differentially endowed resource regions will likely require different resource conservation policy and institutional approaches.

\section{Introduction}

For the western United States, the dominant themes of much of water resource economic research have generally emphasized the need for either greater water use efficiency in agriculture (to enhance farm profitability), or new institutional mechanisms to effect water reallocation to meet increasing demands for urban and industrial uses, recreation and Native American water right claims. While these traditional demands will continue to be a significant force for change in western water reallocation, the 1990s in particular ushered in even stronger forces for change. Water quality and endangered species, as well as ecosystem habitat and biodiversity, are human health and environmental forces dominating the social/political agendas for water resource change at watershed, state and federal levels. Climate change and its impact on resource availability are also a growing concern in the arid west. These forces for change are unlikely to diminish, but rather, they will most likely become stronger and prevail as the dominant forces affecting western water resource use. Such forces are also increasing political and economic pressures to more effectively integrate conservation policy and institutional innovations that together will more readily accommodate both water conservation and water reallocation.

Agriculture's contribution to water quality degradation and environmental impairment is well documented (US Fish and Wildlife Service (USFWS), 1992; 
National Research Council (NRC), 1996; Natural Resource Conservation Service (NRCS), 1996, 1997). Animal waste and farming practices (particularly for irrigated agriculture) are identified as the major sources of non-point-source pollutants (including sediments, nutrients, pesticides, salts and pathogens) impairing water quality in rivers and streams, reservoirs, estuaries and groundwater aquifers (NRCS, 1997; US Environmental Protection Agency (USEPA), 1998; Bricker et al., 1999; US Geological Survey (USGS), 1999). The run-off and leaching of agricultural pollutants also degrades ecosystem habitats, threatens endangered species survival and reduces ecosystem biodiversity (NRC, 1992; Fischman, 1992; NRCS, 1996). Water quality studies conducted by the USGS in selected watersheds found that the nitrate levels in $16 \%$ of the domestic wells under agricultural land (for these watersheds) exceeded the USEPA's maximum contaminant level for safe drinking water (Mueller et al., 1995). High nitrate and phosphorous levels in surface waters, particularly for estuaries, lead to eutrophication and to excess growth of less desirable aquatic plants, which in turn lead to insufficient dissolved oxygen for fish and other marine organisms. While usually detected at low levels, agricultural pesticides remain a serious concern for their risk to human health, as well as for their impact on fish and marine organisms essential for future biodiversity (Barbash \& Resek, 1995; USEPA, 1999; USGS, 1999). Finally, various trace elements from irrigated soils (including boron, arsenic, mercury, molybdenum, chromium, selenium and salts) are commonly transported via irrigation drainage into rivers, streams, reservoirs, wetlands and evaporative ponds. Even at low concentrations in ambient water levels, toxicosis for fish and wildlife may occur over time via bioconcentration and biomagnification, causing reduced survival, deformity, reduced growth and decreased reproductive success (USFWS, 1992).

Irrigated agriculture shares a unique responsibility for reducing the potential human health, ecosystem and biodiversity impacts attributable to nonpoint-source pollutants. For given farm-level agri-environmental, land, soil and hydrological characteristics, irrigation technologies, farm water management practices as well as chemical use practices strongly influence irrigated agriculture's contribution to non-point-source pollution (NRCS, 1997). Improving onfarm irrigation efficiency reduces loadings of nutrients, pesticides and trace elements in irrigation run-off to surface waters, as well as reducing leaching of agrichemicals into groundwater supplies. Thus, for irrigation practices, when a greater proportion of water applied is used beneficially (increased irrigation efficiency), these practices contribute to resource conservation and environmental improvement goals (NRCS, 1997; US Department of Agriculture (USDA), 2001).

This paper addresses the issue of farm water use efficiency/conservation for the US mid-plains states region (Nebraska, South Dakota, Kansas and Wyoming), and draws implications for both conservation policy and institutional perspectives unique to irrigated agriculture designed to enhance both USDA environmental policy goals and western water reallocation. Research results will highlight the weakness of the conventional quantity-based definition of on-farm water conservation and the need for a broader conservation perspective that integrates water conservation policy and institutional reforms. A broader conservation/institutional perspective will need to integrate more effectively policies emphasizing improvements in on-farm water use (efficiency) and innovative institutional mechanisms (water markets, water banks and conserved 
water rights, etc.) that together modify both intensive and extensive margin agricultural water use.

First, adapting the work by Schaible et al. (1991), Parks's modified multinomial logit approach is applied to the mid-plains states region to examine the impact of changing agricultural economic conditions on the transition of irrigation technology to more water-conserving and environmentally enhancing technologies. Secondly, potential irrigation technology transitions and agricultural water conservation are simulated for alternative crop price and irrigation cost scenarios. Thirdly, irrigation technology elasticities are estimated across the four states to provide additional insight for regional policy implementation. Fourthly, results for the mid-plains states region, which is heavily dependent upon groundwater resources, are compared to results for the Pacific north-west (from Schaible et al., 1991), a region heavily dependent upon the use of surface water resources. Regional comparisons highlight the need for integrated conservation/ institutional policies that account for unique regional environmental goals and differences in resource endowments, as well as regional differences in institutional and agri-economic environments and their agricultural production technology settings.

\section{Methods and Model Presentation}

Since the mid-1980s, a variety of empirical studies have examined irrigation technology adoption decisions at field, farm, county and regional levels. Caswell \& Zilberman (1985) used a multinomial logit model of three irrigation technology groups to demonstrate that water price policies could induce adoption of water-conserving irrigation technologies for perennial crop growers in the San Joaquin Valley of California. Caswell \& Zilberman (1986) demonstrated theoretically the importance of field/soil characteristics (land quality) and well depth in the producer field-level irrigation technology decision. Lichtenberg (1989) used county-level, cross-section/time series data and multinomial logit analysis to determine the importance of centre-pivot irrigation technology in explaining the shift in crop production for western Nebraska to more water-sensitive crops (particularly maize). Negri \& Brooks (1990), using a binomial logit framework for two water-conserving technologies and a national cross-section of farm-level data for groundwater irrigators, confirmed the importance of water costs and locational characteristics in the farm-specific technology decision. Schaible et al. (1991) extended Parks's modified multinomial logit approach to evaluate the relative importance of the agricultural economic environment, along with locational factors, in irrigation technology adoption decisions for the Pacific northwest. The authors concluded that in the absence of policy-induced conservation incentives, future irrigation technology transitions for the region would likely be relatively slow. Shrestha \& Gopalakrishnan (1993), using a discrete choice, limited dependent variable approach, confirmed the importance of technical, informational, locational and management factors in field-level decisions for drip irrigation in Hawaii's sugar industry. Green et al. (1996) and Green \& Sunding (1997) used multinomial and binomial logit technology adoption models, respectively, for irrigators growing high-valued crops in the southern San Joaquin Valley of California. When evaluating field-level decisions, these authors confirm the relative importance of economic and land quality characteristics, as well as farmland allocation choices, in the technology adoption decision. 
In summary, each of these studies has made a unique contribution to a broader understanding of the economic, field and farm decision factors influencing farm water use efficiency, as well as the potential for policy to enhance both resource conservation and environmental policy goals. However, most of this research has examined the issue of irrigation technology adoption using conventional, discrete choice adoption frameworks and cross-sectional, single-equation estimation procedures for either two or three technology groups, generally traditional gravity and sprinkler irrigation systems. Research for this paper extended the Schaible et al. (1991) adaptation of Parks's modified multinomial logit model to the mid-plains states region, while also enhancing water conservation policy analysis from several perspectives. First, the research allows for consistent policy comparisons across two differentially endowed water resource regions. Surface water is the dominant source for irrigated agriculture in the Pacific north-west, while groundwater irrigation dominates in the midplains states region. These differences allow this study to identify useful implications for regional conservation policy implementation. In addition, this study examined technology transitions across five technology groups (conventional gravity and sprinkler irrigation systems, as well as a water-conserving gravity and two water-conserving sprinkler systems). Finally, technology transition parameters were estimated using a joint-estimation procedure for a polychotomous discrete choice model that simultaneously recognizes both cross-section and time series influences, as well as adjusting parameter estimators recognizing Parks's (1980) two-component random error term. Parks makes it abundantly clear that conventional implementation of multinomial logit analysis will result in biased estimators.

Consistent with producer-perceived utility-maximizing behaviour (McFadden, 1974, 1976, 1981; Pudney, 1989), irrigation technology choices or their selection probabilities can be written first as the following multinomial logit model:

$$
P_{i}=\frac{e^{D_{i}(X)}}{\sum_{i=0}^{J} e^{D_{i}(X)}} \text { for } i=0,1, \ldots, J
$$

Where: $P_{i}$ is the selection probability for the $i$ th irrigation technology; $D(X)$ is an estimated technology-choice perceived utility function, $U$; and $X$ represents the set of relevant aggregate economic and location/technology attribute vectors, $\left\{C^{\mathrm{p}}, w, L\right\}$, that maximize technology-specific perceived utility $U_{j}=D_{j}\left(C^{\mathrm{p}}, w\right.$, $L)+\varepsilon_{j}$. The vector sets for $C^{\mathrm{p}}$, a vector of crop output prices, $w$, a vector of input prices, and $L$, a vector of location (land) and technology attributes represent the non-stochastic, observable values defining irrigator perceptions of the relative profitability of alternative irrigation technology choices. The terms $\varepsilon_{j}$ identify that part of the producer technology decision which reflects the vector of values for unobservable, unmeasurable attributes, as well as the unobservable random values for producer perceptions of observable and unobservable attributes. The values $\varepsilon_{j}$ are assumed to be independent random variations identically distributed with the Weibull distribution.

Normalized technology selection probabilities are expressed as:

$$
p_{i}=\frac{e^{\left(d_{i}\right)}}{1+\sum_{i=1}^{J} e^{\left(d_{i}\right)}} \text { for } i=1, \ldots, J \quad \text { and } p_{0}=\left[1+\sum_{i=1}^{J} e^{\left(d_{i}\right)}\right]^{-1}
$$


The function $d_{i}$ in equation (2), expressed as:

$$
d_{i}=\beta_{i 1} X_{1}+\beta_{i 2} X_{2}+\ldots+\beta_{i K} X_{K}+\varepsilon_{i}
$$

for technology choice $i=1, \ldots, J$ represents the difference in perceived utility between producer technology choice sets $\left(P_{i}\right)$ and $\left(P_{0}\right)$, expressed as a linear function of the non-stochastic observable values for the vector $X$ and the random error $\varepsilon_{i}$.

Because applied research uses observed proportions $p_{i}$ and not actual selection probabilities $P_{i}$, estimated technology logit equations must account for both conventional specification and approximation random error terms (Amemiya \& Nold, 1975; Parks, 1980). Using equations (2) and (3), multiregional, temporal logit equations reflecting polychotomous irrigation technology decisions are then represented as:

$$
d_{i m t} \approx \ln \left(p_{i m t} / p_{0 m t}\right)=\sum_{k=1}^{K} \beta_{i k} X_{k m t}+\varepsilon\left(v_{i m t}+u_{i m t}\right)
$$

where: $i=1, \ldots, J$ (irrigation technology groups); $m=1, \ldots, M$ (regional cross-sections); $t=1, \ldots, T$ (years); and the vector $X$ represents locational characteristic variables and agricultural economy variables measuring the log of real output to irrigation energy (water pumping cost) price ratios. Here the normalized technology choice is measured as the log of the odds of choice $p_{\text {imt }}$ to $p_{0 m t}$, while $v_{\text {imt }}$ and $u_{i m t}$ are the specification and approximation random error terms, respectively, assumed to be independent (Parks, 1980). (The mean and variance/ covariance estimators and their properties for this cross-section/temporal, modified multinomial logit model are discussed in Parks (1980) and Schaible et al. (1991).)

The model is estimated using Zellner \& Lee's (1965) joint-estimation procedure, but with Aitken estimators adjusted for heteroscedasticity and crosssection correlation. In addition, the estimated cross-choice covariance matrix was corrected for a first-order autoregressive error structure based on Parks's (1967) cross-section, time series estimation procedure. Estimated parameters are both consistent and asymptotically more efficient than standard multinomial logit estimators (Parks, 1980).

\section{Mid-plains States Irrigated Agriculture and Applied Model}

Both intensive and extensive margin irrigated agriculture contribute to nonpoint-source pollution and groundwater contamination in the mid-plains states region. Nearly 12 million acres ${ }^{1}$ were irrigated in the region in 1997, 11 million crop acres and about 0.7 million pastureland acres (National Agricultural Statistics Service (NASS), 1999a). Nebraska and Kansas account for the majority of the region's irrigated acres, 59.3\% and 23.1\%, respectively. Wyoming, with only $14.7 \%$ of the region's irrigated acres, accounts for $77.6 \%$ of the region's irrigated pastureland acres. Maize for grain, wheat, soybeans and hay dominate the regional irrigated cropping pattern $(56.6 \%, 5.4 \%, 10.8 \%$ and $13.6 \%$ of total irrigated acres, respectively). Relative to total irrigated acres, maize and wheat are the dominant irrigated crops in Kansas, $72.3 \%$; maize and soybeans in Nebraska, 85.6\%; maize, soybeans and hay in South Dakota, 85.0\%; and irrigated hay and pastureland in Wyoming, 83.9\%. Irrigated agriculture accounts for $76.5 \%$ of total freshwater withdrawals for the region, and $93.5 \%$ of total con- 
sumptive use of freshwater withdrawals (Solley et al., 1998). Groundwater is the dominant water source for irrigation in Nebraska and Kansas, averaging about $82 \%$ of withdrawals by irrigated agriculture. Surface water, primarily from off-farm supplies, is the dominant source for irrigation in South Dakota and Wyoming, averaging about $96 \%$ of withdrawals by irrigated agriculture. Historically, gravity systems dominated irrigation technology in the region, but as of 1998, 60.5\% of irrigated acres used pressure sprinkler systems (NASS, 1999b). About half of sprinkler irrigated acres are still irrigated using conventional centre-pivot sprinkler systems (medium- to high-pressure systems), and only about $20 \%$ of gravity irrigated acres make use of improved (water-conserving) gravity systems. However, most of the technology transition to improved irrigation technology has occurred in Kansas, most likely due to generally higher pumping lifts and, therefore, higher irrigation pumping costs. Even so, nearly two-thirds of irrigated acres for the region are still irrigated with conventional gravity and sprinkler technologies.

Pooled data for Kansas, Nebraska, South Dakota and Wyoming over the period 1974-95 were used to jointly estimate a four-equation, modified multinomial logit model of irrigation technology transitions as a probabilistic function of regional agroclimatic characteristics and time-dependent economic variables. Using cross-sectional, time series data extends the capability of the multinomial logit framework, allowing the opportunity to evaluate the role of the timedependent farm economic environment in irrigation technology transitions and potential water conservation. This extension does not diminish the important role of micro, field/farm characteristic data in technology adoption studies. However, micro data are useful only when evaluating the likely adoption for a particular field/farm decision, that is, the intensive margin irrigation decision. A pooled data approach enhances the ability to use the multinomial logit framework to evaluate broader, extensive margin, conservation policy/institutional issues.

With conventional gravity irrigation systems as the reference technology, $P_{0}$, technology transition equations were estimated for: improved gravity systems, $P_{1}$ (such as surge flow and cablegation systems, and gravity systems using tail water recovery); conventional sprinkler systems, $P_{2}$ (including mechanical and hand-move systems, and solid-set/permanent systems); high-pressure centrepivot systems, $P_{3}$; and lower-pressure ( $<60$ pounds per square inch) centrepivot systems, $P_{4}$. Less than $1.0 \%$ of irrigated acres for the region are irrigated with drip/trickle or micro-sprinkler systems, and so this technology category was dropped from the analysis. The logs of real crop price to energy (water pumping cost) price ratios for each of the mid-plains states for feed grains, wheat, hay and soybeans were used to explain the influence of changing regional agricultural economic conditions. Because the region is heavily groundwater-dependent, normalized real output to energy price ratios are believed to appropriately capture the dominant price vector effects. State dummy variables were used to capture regional agroclimatic characteristics.

Irrigation technology shares by state were obtained from annual data reported in the Irrigation Journal, 1975-96, January/February issues, with adjustments made to disaggregate centre-pivot sprinkler shares between high- and lowerpressure systems using data from Sloggett (1985) and the 1988 and 1994 Farm and Ranch Irrigation Surveys (FRISs). Energy cost per acre foot for each technology group, or irrigation pumping costs, were estimated (using aggregate engineering cost relationships) as the weighted-average cost of pumping an acre foot of water to field level, weighted across irrigation energy sources, water 
sources and pumping lifts by state using a variety of data sources (including the Irrigation Journal (for data on energy shares), 1975-96; FRISs (for 1984, 1988 and 1994); Sloggett, 1985; and Dugan \& Cox, 1994). Energy prices by energy source were obtained from the annual price summary series published by NASS (1972-95c), Department of Energy (DOE) (1992, 1993) and Sloggett (1985). Crop prices reflect a season-average market price using data from agricultural prices and agricultural production (NASS, 1972-95a,b), plus an average deficiency payment per unit of production estimated using data from USDA's Farm Service Agency (FSA) (1972-95). Indices of prices received by crop category (USDA) and indices of prices paid for fuels and energy (USDA) were used to convert prices to 1995 dollars.

\section{Model Estimation Results}

Joint-equation estimation results for the mid-plains states are presented in Table 1. A joint-equation $R^{2}$ of 0.85 , along with the statistical significance of both locational and most economic variables, and relatively small Theil $U$-coefficient values (see Tables 1 and 2), demonstrates that the estimated equations are valid relationships. Statistical results also indicate that the estimated equations are a useful predictor of expected mid-plains irrigation technology transitions, as well as the likely water conservation associated with technology transitions under alternative agricultural economic assumptions. Consistent with previous studies, state-specific variables are all statistically significant and greater than 1, confirming the importance of locational characteristics in irrigation technology adoption decisions. In addition, the relatively greater size of the locational coefficients for equation $\ln \left(P_{4} / P_{0}\right)$, for lower-pressure centre-pivot systems, confirms results by Schaible et al. (1991) that locational factors likely play a more significant role in the pace of irrigation technology transitions, the more waterconserving the technology. Coefficients for the respective price variables reflect the relative responsiveness of the odds of adopting the $i$ th irrigation technology to conventional gravity technology $P_{0}$. Coefficients for crop price variables for most equations are less than 1, indicating that partial crop price effects on mid-plains irrigation technology transitions are generally relatively small. However, for lower-pressure centre-pivot technology, the relative size of the price coefficients likely indicates that adoption is probably slightly more crop price responsive, which more than likely reflects producer efforts to improve economic returns through conservation, while also promoting environmental goals.

\section{Mid-plains States Simulation Results}

Producers in the mid-plains states region will likely continue to adopt waterconserving irrigation technologies. However, under alternative assumptions for the region's agri-economic environment, relevant conservation policy considerations include both the likely pace of technology transitions and its expected water conservation and environmental implications. Equation (2) and estimated coefficients from Table 1 are used to simulate irrigation technology proportions for the mid-plains states from 1995 to 2015 for three alternative crop/energy price scenarios. Alternative agri-economic conditions were specified by state assuming annual changes in real crop/energy price ratios based on the historical annual average real price change for the period 1973-96 (Table 3). For Scenario I, the baseline economic environment, real prices for wheat, hay and soybeans are increased annually at their historical annual average real price change. Real 
Table 1. Joint-equation estimation results for log of odds, irrigation technology transitions for the mid-plains states (Kansas, Nebraska, South Dakota and Wyoming)

\begin{tabular}{|c|c|c|c|c|c|c|c|c|}
\hline \multirow[b]{2}{*}{ Equation $^{\mathrm{a}}$} & \multirow[b]{2}{*}{ Constant } & \multirow[b]{2}{*}{$\operatorname{KanD}^{\mathrm{b}}$} & \multirow[b]{2}{*}{ NebD } & \multirow[b]{2}{*}{ WyD } & \multicolumn{4}{|c|}{$\begin{array}{l}\text { Log of real output to energy (pumping } \\
\text { cost) price ratios }\end{array}$} \\
\hline & & & & & Feed grain & Wheat & Hay & Soybeans \\
\hline $\ln \left(\frac{P_{1}}{P_{0}}\right)^{c}$ & $\begin{array}{c}-0.7810^{* *} \\
(0.4213)\end{array}$ & $\begin{array}{r}2.4340^{*} \\
(0.2144)\end{array}$ & $\begin{array}{r}1.8810^{*} \\
(0.2068)\end{array}$ & $\begin{array}{r}-3.1360^{*} \\
(0.1957)\end{array}$ & $\begin{array}{c}0.1453 \\
(0.1762)\end{array}$ & $\begin{array}{r}0.4095^{*} \\
(0.1601)\end{array}$ & $\begin{array}{r}0.5939^{*} \\
(0.1477)\end{array}$ & $\begin{array}{r}-0.4163^{*} \\
(0.1410)\end{array}$ \\
\hline $\ln \left(\frac{P_{2}}{P_{0}}\right)$ & $\begin{array}{r}1.3491^{*} \\
(0.3638)\end{array}$ & $\begin{array}{r}-2.0398^{*} \\
(0.1886)\end{array}$ & $\begin{array}{r}-1.2445^{*} \\
(0.1827)\end{array}$ & $\begin{array}{r}-1.9506^{*} \\
(0.1690)\end{array}$ & $\begin{array}{c}-0.0093 \\
(0.1570)\end{array}$ & $\begin{array}{r}-0.3279^{*} \\
(0.1366)\end{array}$ & $\begin{array}{r}-0.6523^{*} \\
(0.1251)\end{array}$ & $\begin{array}{r}0.3668^{*} \\
(0.1185)\end{array}$ \\
\hline $\ln \left(\frac{P_{3}}{P_{0}}\right)$ & $\begin{array}{r}2.6831^{*} \\
(0.5498)\end{array}$ & $\begin{array}{r}-1.2701^{*} \\
(0.2878)\end{array}$ & $\begin{array}{r}-1.3220^{*} \\
(0.2830)\end{array}$ & $\begin{array}{r}-4.9002^{*} \\
(0.2648)\end{array}$ & $\begin{array}{c}0.0591 \\
(0.2373)\end{array}$ & $\begin{array}{c}0.3358 \\
(0.2265)\end{array}$ & $\begin{array}{r}-0.4526^{*} \\
(0.1925)\end{array}$ & $\begin{array}{r}0.5407^{*} \\
(0.1910)\end{array}$ \\
\hline $\ln \left(\frac{P_{4}}{P_{0}}\right)$ & $\begin{array}{r}-5.1997^{*} \\
(0.4708)\end{array}$ & $\begin{array}{c}6.1071^{*} \\
(0.2536)\end{array}$ & $\begin{array}{r}4.0783^{*} \\
(0.2427)\end{array}$ & $\begin{array}{r}-8.9091^{*} \\
(0.2507)\end{array}$ & $\begin{array}{r}-1.2675^{*} \\
(0.1945)\end{array}$ & $\begin{array}{r}4.9252^{*} \\
(0.1874)\end{array}$ & $\begin{array}{c}2.6609^{*} \\
(0.1700)\end{array}$ & $\begin{array}{r}-1.6954^{*} \\
(0.1687)\end{array}$ \\
\hline
\end{tabular}

${ }^{a}$ Numbers in parentheses are estimated standard errors. ${ }^{*}$ Significance at $5 \%$; $* *$ significance at $10 \%$.

${ }^{\mathrm{b}}$ Locational variables for Kansas (KanD), Nebraska (NebD) and Wyoming (WyD). South Dakota is the reference state.

${ }^{\mathrm{c}}$ Multinomial logit equations for the irrigation technology states: $P_{0}=$ conventional gravity systems; $P_{1}=$ improved gravity systems; $P_{2}=$ conventional sprinkler systems; $P_{3}=$ high pressure centre-pivot systems; and $P_{4}=$ lower pressure centre-pivot systems.

Note: Joint-equation estimation $R^{2}=0.8451$.

prices for feed grains and energy were held at their 1995 real price levels for all scenarios because real prices for feed grains across the region declined over the historical period (except for Wyoming), and real prices for energy also declined for Nebraska and South Dakota (Table 3). For Scenario II, the historical annual average baseline real prices for wheat, hay and soybeans are increased by $30 \%$. For Scenario III, the historical annual average baseline real prices are increased by only $10 \%$. While numerous other price scenarios are possible, these three likely capture the essential range of impacts.

Simulated irrigation technology shares for the mid-plains states are presented in Table 4. Under baseline economic assumptions, one can expect mid-plains irrigated agriculture to make a moderately significant transition to a more

Table 2. Theil's $U$-coefficients by irrigation technology group ${ }^{a}$

\begin{tabular}{lccccc}
\hline & $P_{0}$ & $P_{1}$ & $P_{2}$ & $P_{3}$ & $P_{4}$ \\
\hline Kansas & 0.2288 & 0.0626 & 0.1707 & 0.1348 & 0.2470 \\
Nebraska & 0.1078 & 0.0745 & 0.0644 & 0.0924 & 0.3242 \\
South Dakota & 0.1728 & 0.1745 & 0.3916 & 0.1183 & 0.3160 \\
Wyoming & 0.0825 & 0.3809 & 0.0984 & 0.1522 & 0.2520 \\
Mid-plains region & 0.0885 & 0.1106 & 0.3277 & 0.1161 & 0.2830 \\
\hline
\end{tabular}

a Theil's $U$-coefficient values equal to zero indicate that historical simulated results are perfect. Values equal to 1 indicate no relationship (Chan, 1981). 
Table 3. Average annual real price changes: mid-plains states, 1973-96

\begin{tabular}{lccccc}
\hline State & $\begin{array}{c}\text { Feed grains } \\
(\$ / \text { bu. })\end{array}$ & $\begin{array}{c}\text { Wheat } \\
(\$ / \text { bu. })\end{array}$ & $\begin{array}{c}\text { Hay } \\
(\$ / \text { ton })\end{array}$ & $\begin{array}{c}\text { Soybeans } \\
(\$ / \text { bu. })\end{array}$ & $\begin{array}{c}\text { Energy (pumping cost }) \\
(\$ / \text { acre foot })\end{array}$ \\
\hline Kansas & -0.0144 & 0.0401 & 1.3969 & 0.0236 & 0.1916 \\
Nebraska & -0.0095 & 0.0519 & 0.5603 & 0.0265 & -0.0527 \\
South Dakota & -0.0029 & 0.0343 & 0.7056 & 0.0059 & -0.0934 \\
Wyoming & 0.0150 & 0.0549 & 1.8000 & 0.0059 & 0.0097 \\
\hline
\end{tabular}

water-conserving and environmentally conscious production environment. Simulation results demonstrate that if real crop prices (for only wheat, hay and soybeans) increase annually at their historical average real price change (and real feed grain prices at least remain constant), then lower-pressure centre-pivots could dominate irrigation technology in use in Kansas in 2015, increasing from a $34.5 \%$ to a $71.0 \%$ share, while also significantly increasing in the remainder of the region. Under baseline economic assumptions, by 2015 lower-pressure centre-pivot systems will likely increase by $36.5 \%$ in Kansas, $22.5 \%$ in Nebraska, $29.4 \%$ in South Dakota and 20.3\% in Wyoming. Even though local technology transitions may differ, in the aggregate, transitions to lower-pressure centrepivot systems will originate from a decline in use of all other gravity and sprinkler irrigation systems across the region, except for Wyoming. In Wyoming, irrigated agriculture consists primarily of irrigated hay and pastureland, currently irrigated using primarily conventional gravity systems (including flood and gated-pipe/siphon-tube systems). Given an initial share of nearly $80 \%$ for conventional gravity systems, it is understandable that transitions to water-conserving gravity systems, while relatively small for Wyoming, will be captured for Wyoming but not for the remainder of the region. Even so, use of improved gravity irrigation systems (including surge flow, cablegation and gated-pipe with tail water recovery systems) increases only slightly across Wyoming, while use of lower-pressure centre-pivots could increase by about $20 \%$.

Results for Scenarios II and III show that an increase in the baseline annual average real price change, by $30 \%$ and $10 \%$, respectively, results in only modest increases (over baseline estimates) in irrigation technology transitions across the region. An increase in baseline real price changes, by $10 \%$ (Table 4 , Scenario III), results in an increase in the proportion of acres being irrigated with lower-pressure centre-pivot systems (over baseline relative changes) by $2.6 \%$, $2.8 \%, 3.2 \%$ and $3.6 \%$ for Kansas, Nebraska, South Dakota and Wyoming, respectively. If baseline real price changes increase by $30 \%$ (Scenario II), the relative change for lower-pressure centre-pivot systems would increase (over baseline relative changes) by $7.2 \%, 8.6 \%, 9.3 \%$ and $11.4 \%$ for the mid-plains states, respectively. Such modest changes in technology transitions, even given a significant increase in baseline real price changes, probably imply for the region that producer irrigation technology adoption decisions are relatively crop price inelastic. It is worth noting, however, that the greater relative impact on technology transitions due to real price increases will more likely occur in South Dakota and Wyoming. However, this is not surprising given that for Wyoming, conventional gravity systems (at $80.1 \%$ ) dominate present irrigation technology use (NASS, 1999b). For South Dakota, current irrigation systems include 


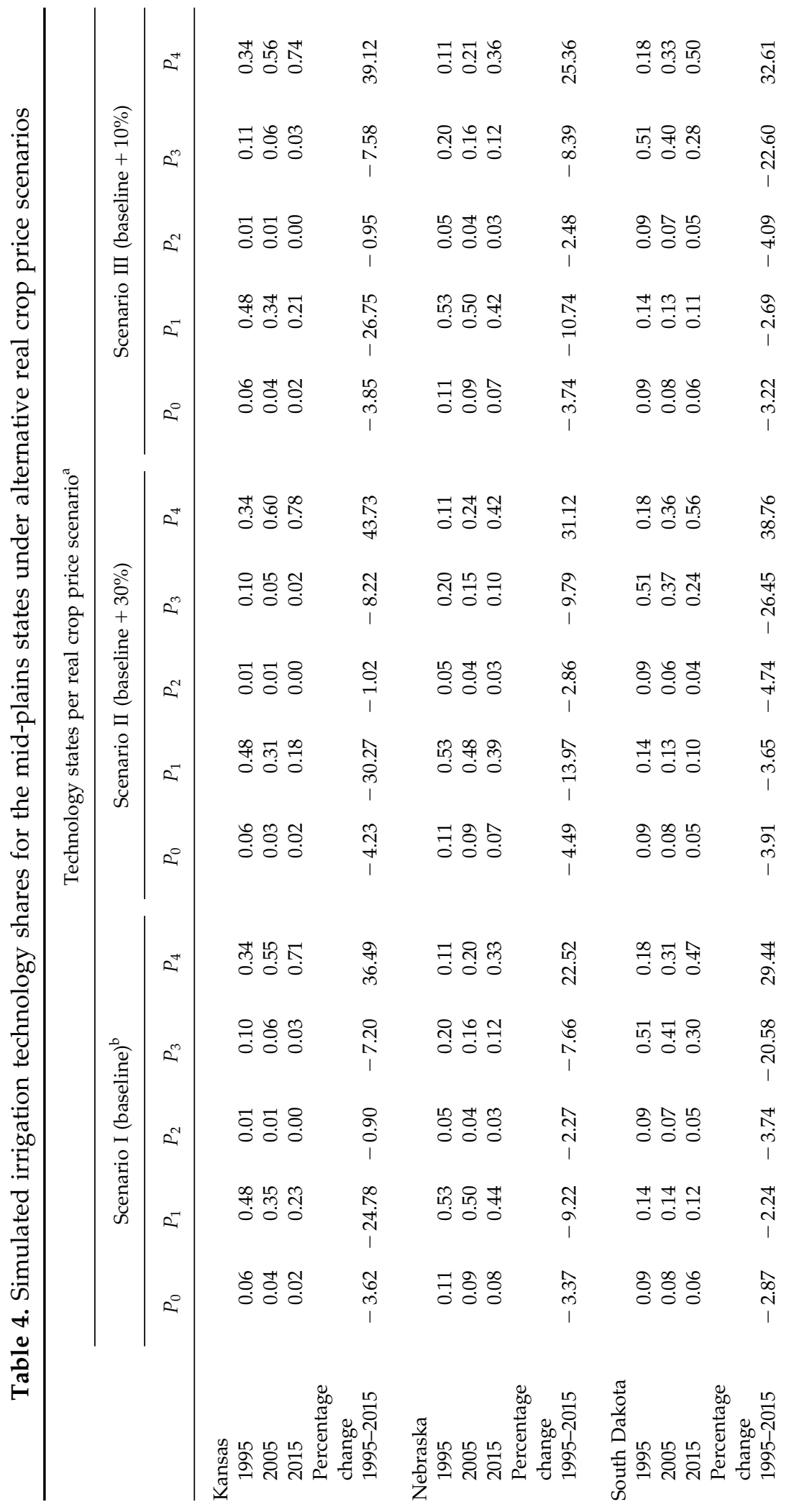




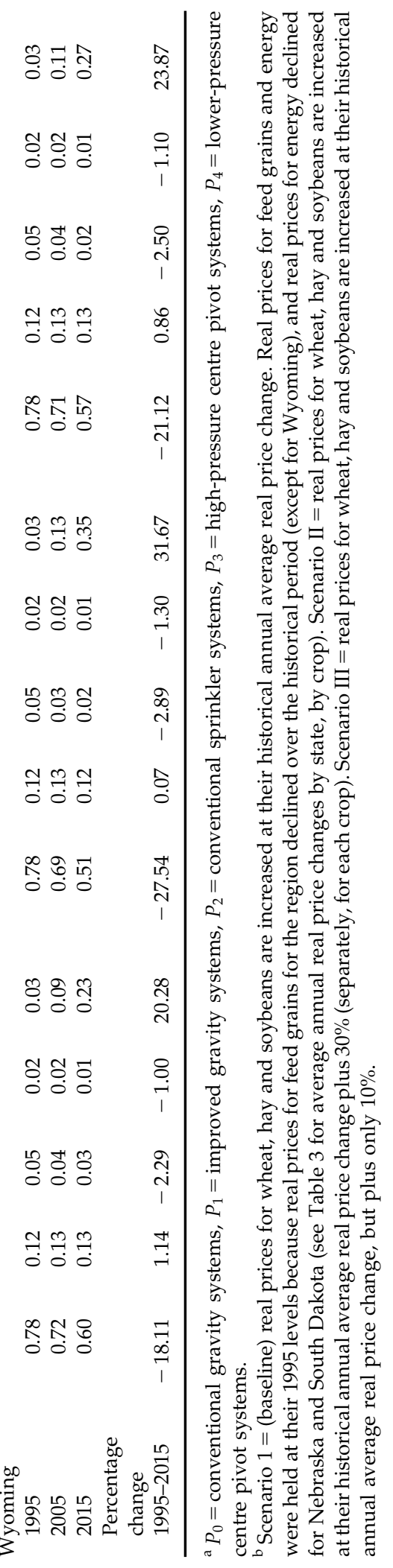


Table 5. Irrigation technology response elasticities for the mid-plains states, 1995-2015, relative to an increase in real crop price for wheat, soybeans or hay, respectively ${ }^{\mathrm{a}, \mathrm{b}}$

\begin{tabular}{|c|c|c|c|c|c|}
\hline & \multicolumn{5}{|c|}{ Irrigation technology state ${ }^{c}$} \\
\hline & $P_{0}$ & $P_{1}$ & $P_{2}$ & $P_{3}$ & $P_{4}$ \\
\hline \multicolumn{6}{|c|}{$\begin{array}{l}\text { Relative to an increase } \\
\text { in real wheat price }\end{array}$} \\
\hline Kansas & -0.44 & -0.38 & -0.51 & -0.50 & 0.34 \\
\hline Nebraska & -0.30 & -0.21 & -0.37 & -0.36 & 0.73 \\
\hline South Dakota & -0.20 & -0.15 & -0.24 & -0.25 & 0.49 \\
\hline Wyoming & -0.10 & -0.02 & -0.19 & -0.14 & 0.98 \\
\hline \multicolumn{6}{|c|}{$\begin{array}{l}\text { Relative to an increase } \\
\text { in real soybean price }\end{array}$} \\
\hline Kansas & 0.05 & 0.02 & 0.07 & 0.10 & -0.08 \\
\hline Nebraska & 0.02 & -0.02 & 0.05 & 0.07 & -0.13 \\
\hline South Dakota & 0.00 & -0.01 & 0.01 & 0.01 & -0.04 \\
\hline Wyoming & 0.00 & -0.01 & 0.00 & 0.00 & -0.04 \\
\hline \multicolumn{6}{|c|}{$\begin{array}{l}\text { Relative to an increase } \\
\text { in real hay price }\end{array}$} \\
\hline Kansas & -0.49 & -0.31 & -0.66 & -0.61 & 0.30 \\
\hline Nebraska & -0.11 & -0.01 & -0.23 & -0.19 & 0.36 \\
\hline South Dakota & -0.15 & -0.02 & -0.27 & -0.24 & 0.44 \\
\hline Wyoming & -0.11 & 0.11 & -0.35 & -0.22 & 0.87 \\
\hline
\end{tabular}

${ }^{a}$ Real crop price changes for feed grains were accounted for in estimating the modified multinomial logit (MML) model; however, real feed grain prices declined over the study period for the study area (except for Wyoming), so simulation analysis was conducted only for real price increases for wheat, soybeans and hay.

${ }^{\mathrm{b}}$ Simulated elasticity values were measured as the relative change in the technology share for 2015 between a simulation scenario assuming a historical annual average real price change for the crop price of interest, and a scenario increasing that real price change by $10 \%$, all relative to the $10 \%$ real price change.

${ }^{\mathrm{c}}$ Irrigation technology states are: $P_{0}=$ conventional gravity systems; $P_{1}=$ improved gravity systems; $P_{2}=$ conventional sprinkler systems; $P_{3}=$ high pressure centre pivot systems; and $P_{4}=$ lower-pressure centre pivot systems.

conventional gravity systems (at 30.4\%) and high-pressure centre-pivot systems (at $49.8 \%$ ).

Intermediate technology-specific response elasticities were evaluated by state, separately for wheat, soybean and hay real price changes (Table 5). For the mid-plains states, the responsiveness of producer irrigation technology transitions to real crop price increases is relatively inelastic, a result which confirms the authors' earlier discussion. These results likely imply for the region that transitions to water-conserving irrigation technology may also be driven by the need to conserve water due to lowering water tables (that is, perceived resource scarcity), the desire to lower farm income risk and possibly some valid producer environmental concerns.

Water conservation estimates associated with irrigation technology transitions were estimated for each scenario under two alternative assumptions for agricultural water use rates. First, water conservation was determined by applying weighted technology-specific water use rates from the 1994 FRIS to irrigated 
acreage shifts associated with simulated technology shares by scenario (from Table 4). Secondly, water conservation estimates were also determined using computed technology-specific water use rates derived applying both weighted irrigation efficiency rates and consumptive use rates from crop-specific consumptive use data (Soil Conservation Service, USDA, 1976). Both approaches are used because it is commonly believed (a general consensus of the Western Regional Research Committee on water resources, W190) that producerprovided FRIS water use rates are probably low, that is, closer to more commonly recognized crop consumptive use rates. FRIS data, then, provide a lower-bound water conservation estimate based on producer-perceived water use, while computed water use rates provide an engineering-based, upperbound conservation estimate for technology transitions by scenario. Conservation estimates for both approaches, representing a range of expected annual agricultural water conservation by 2015, are presented in Table 6 .

First, results suggest that regional conservation estimates may differ significantly depending upon one's assumption about actual water use rates. If FRIS water use rates are more actual than perceived, then baseline agri-economic conditions result in only modest annual agricultural water conservation by 2015 . However, the closer actual water use rates are to computed engineering-based rates, then baseline agri-economic conditions alone could potentially produce more significant agricultural water conservation for the mid-plains region. By 2015, assuming no change in regional extensive margin irrigation, regional agriculture will likely be using less water, ranging from 0.27 million acre feet to 1.15 million acre feet less water use annually (Table 6). This level of conservation would range from $2.3 \%$ to $9.8 \%$ of agriculture's 1998 regional water use (NASS, $1999 b)$. Given that much of this conservation will result in both reduced run-off and deep percolation, an improved aggregate agricultural water use efficiency for the region ranging from $2.3 \%$ to $9.8 \%$ will likely also have at least a noticeable impact on reducing agriculture's contribution to non-point-source pollution, thereby contributing to both water quality and ecosystem benefits. Conservation results for Scenarios II and III indicate that an increase in the baseline real price change for wheat, soybeans and hay, by $30 \%$ and $10 \%$ for Scenarios II and III, respectively, will only have a marginal impact on further reducing agricultural water use for the region, ranging from $3.3 \%$ to $13.6 \%$ and $2.6 \%$ to $11.1 \%$, respectively.

The results in Table 6 also clearly indicate a difference in the location of agricultural water conservation for the two conservation measurement approaches. Based on reported, aggregate FRIS water use rates, nearly $72 \%$ of baseline conservation for the region is reported to occur in Nebraska. However, when using engineering-based estimates of actual water use rates, baseline conservation is reported to be more regionally distributed, $19.7 \%$ for Kansas, $41.5 \%$ for Nebraska, $2.7 \%$ for South Dakota and 36.1\% for Wyoming. These differences likely mean that not only are the producer-perceived FRIS water use rates probably low, but that significant regional variation also exists in producer perceptions of actual agricultural water use. These differences, no doubt, would likely add regional (state- and/or watershed-specific) complexity to the implementation of conservation policy designed to reduce irrigated agriculture's impact on non-point-source pollution. However, such complexity should not be a deterrence to policies encouraging greater agricultural water use efficiency for the mid-plains region. 


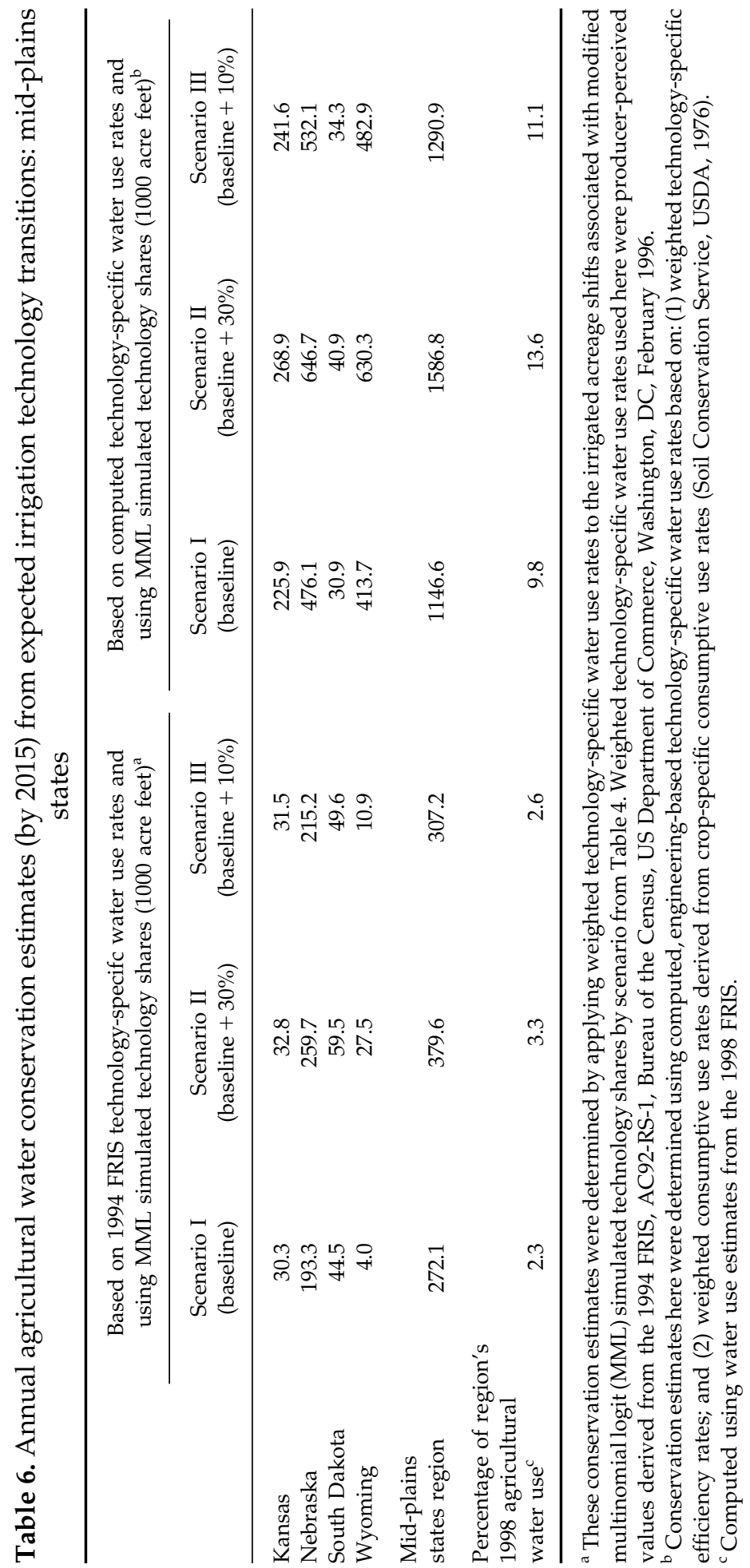


Table 7. Irrigation technology transitions for the Pacific north-west

\begin{tabular}{|c|c|c|c|c|c|c|}
\hline \multirow[b]{3}{*}{ State } & \multicolumn{6}{|c|}{ Relative changes in irrigation technology shares, 1986-2005 (\%) } \\
\hline & \multicolumn{3}{|c|}{ Baseline $^{\mathrm{a}}$} & \multicolumn{3}{|c|}{ Baseline $+30 \%$} \\
\hline & $P_{0}$ & $P_{1}$ & $P_{2}$ & $P_{0}$ & $P_{1}$ & $P_{2}$ \\
\hline Idaho & -15.9 & 10.1 & 5.8 & -19.2 & 11.9 & 7.3 \\
\hline Oregon & -12.2 & 8.6 & 3.6 & -14.5 & 9.9 & 4.6 \\
\hline Washington & -8.0 & 5.1 & 2.9 & -9.7 & 6.0 & 3.7 \\
\hline
\end{tabular}

Source: Schaible et al. (1991, table 5, Scenarios III (baseline) and IV (baseline $+30 \%)$ ).

a Baseline scenario: real prices were increased annually for wheat, alfalfa and energy by their historical annual average real price change (for the Pacific north-west). Baseline $+30 \%$ scenario: incorporates baseline real price changes plus $30 \%$. Technology states for Pacific north-west study: $P_{0}=$ gravity systems; $P_{1}=$ conventional sprinkler systems; and $P_{2}=$ centre-pivot sprinkler systems.

\section{Regional Simulation Comparisons}

The differing pace of irrigation technology transitions to water-conserving technologies across regions, and even across watersheds, contributes to differences in water quality and ecosystem impacts, largely through their effect on agricultural water use efficiency. The authors compare the technology/ conservation simulation results for this study with results from an earlier study for the Pacific north-west region (Schaible et al., 1991). While the two studies differed slightly in the number of modelled technology groups (five were modelled for the mid-plains states and three for the Pacific north-west study), the same modelling methodology was applied and essentially the same data sources were used for both studies. These similarities make it possible to compare technology/conservation simulation results for the two study regions.

From a policy perspective, comparing results for the two regions is important because of the ability for consistent policy analysis across two differentially endowed water resource regions, and their potential implications for regionally different policy/institutional design. In the mid-plains states, groundwater is the dominant water source for most irrigated agriculture, accounting for $68.1 \%$ for the region, but $97.5 \%$ and $84.2 \%$ for Kansas and Nebraska, respectively (NASS, 1999b). Nebraska and Kansas account for about $82 \%$ of the region's irrigated acres. In the Pacific north-west, surface water is the dominant water source for irrigated agriculture, at about $73.8 \%$ for the region, with Idaho at $67.2 \%$, Oregon at $84.3 \%$ and Washington at $75.4 \%$ (NASS, 1999b).

Tables 7-9 present summarized simulation results from the Pacific north-west study for: the relative change in irrigation technology shares for the Pacific north-west (under similar agri-economic assumptions used for the mid-plains region) (Table 7); simulated technology response elasticities by Pacific northwest state for a real price increase for wheat (Table 8); and estimated annual water conservation in 2005 associated with Pacific north-west simulated technology shares (Table 9). However, conservation estimates for the Pacific north-west study were based solely on producer-estimated (perceived) water use rates (FRIS aggregate rates) by irrigation technology. Therefore, comparisons of Pacific north-west and mid-plains conservation results are only appropriate with mid- 
Table 8. Irrigation technology response elasticities for the Pacific north-west (relative to a real price increase for wheat) ${ }^{a}$

\begin{tabular}{lccc}
\hline State & $P_{0}$ & $P_{1}$ & $P_{2}$ \\
\hline Idaho & -0.02 & -0.01 & 0.10 \\
Oregon & -0.02 & -0.01 & 0.11 \\
Washington & -0.01 & -0.01 & 0.06 \\
\hline
\end{tabular}

a Computed using results from Scenarios I and II, table 5, Schaible et al. (1991). Relative changes in technology proportions were normalized to a $1 \%$ price change to proxy simulated elasticities.

plains estimates presented for Scenarios I and II (columns 1 and 2) in Table 6. Results for the Pacific north-west study reflect simulation over 19 years, 19872005 (the estimation period was 1974-86), while results for the mid-plains reflect simulation over 20 years, 1996-2015 (the estimation period was 1974-95).

Transitions to water-conserving irrigation technology are generally more significant in the mid-plains than in the Pacific north-west. Under baseline economic assumptions for both study regions, the relative shift to conserving technology in the mid-plains ranges from $20 \%$ to $36 \%$ across the region for 1996-2015 (Table 4), while relative technology shifts for the Pacific north-west ranged from about 3\% to 6\% across the region from 1987 to 2005 (Table 7). As indicated in Schaible et al. (1991), both institutional barriers to farm resource use adjustments (such as 'use it or lose it' beneficial use criteria) and relatively low purchased water costs encourage stability with irrigators' initial investments, that is, in the Pacific north-west 'technology in place tends to remain in use'. In the mid-plains region, however, several factors seem to make irrigators more sensitive to the need for water use adjustments in the interest of both farm profitability and long-term irrigation sustainability. First, an increase in real energy price will generally have a more significant cost impact for much of irrigated agriculture in the mid-plains than in the Pacific north-west. Because of a greater dependence on groundwater, increased irrigation costs due to pumping lifts (particularly for areas with declining aquifer water tables) and generally lower profit margins associated with field crop production, a real energy price increase likely makes a mid-plains irrigator more sensitive to the economic

Table 9. Estimated annual water conservation in 2005 for the Pacific north-west (1000 acre feet)

\begin{tabular}{lcc}
\hline State & Baseline & Baseline $+30 \%$ \\
\hline Idaho & 252.9 & 304.1 \\
Oregon & 89.4 & 106.1 \\
Washington & 61.3 & 74.6 \\
Region & 403.6 & 484.8 \\
Percentage of region's 1998 & & \\
agricultural water use $^{\mathrm{a}}$ & 3.2 & 3.8 \\
\hline
\end{tabular}

Source: Schaible et al. (1991, table 6, Scenarios III and IV).

${ }^{\text {a }}$ Computed using water use estimates from the 1998 FRIS. 
benefits of water conservation. Secondly, mid-plains irrigators (dependent primarily on finite groundwater supplies) also likely have a greater perceived sense of resource scarcity than do Pacific north-west irrigators (who depend primarily on publicly supplied, off-farm surface water supplies). Heightened awareness, then, of both economic benefits due to a tighter cost-push environment for irrigated agriculture and perceived resource scarcity likely motivate transitions to water-conserving irrigation technologies more in the mid-plains than in the Pacific north-west.

Increasing historical real price changes by $30 \%$ had a minimal impact on the relative change (from baseline) in water-conserving technology shares for the Pacific north-west, ranging from $0.8 \%$ to $1.6 \%$ (Table 7 ), while having only a modest impact on relative changes (from baseline) for the mid-plains region, ranging from $7.2 \%$ to $11.4 \%$ (Table 4 ). Technology response elasticities in Tables 5 and 8 confirm that real crop price increases have a slightly larger impact on water-conserving technology adoption in the mid-plains than in the Pacific north-west. Even so, technology response elasticities are relatively crop price inelastic for both regions.

Based on producer-perceived FRIS water use rates by technology group, water conservation associated with baseline economic assumptions are rather modest for both study regions (Tables 6 and 9). Relative to 1998 agricultural water use for each region (NASS, 1999b), baseline technology transitions over 19 years for the Pacific north-west and 20 years for the mid-plains would improve aggregate agricultural water use efficiency by $3.2 \%$ for the Pacific north-west and $2.3 \%$ for the mid-plains. An increase in historical annual average real price changes by $30 \%$ has a relatively minor impact on improving water use efficiency beyond baseline estimates for both regions. So, even though transitions to water-conserving technology are relatively greater for the mid-plains, annual water conservation would likely have a slightly greater relative impact for the Pacific north-west than for the mid-plains. This shift in relative aggregate conservation impact is explained by the differences in the type of technology transitions occurring between the two regions. The aggregate annual conservation impact is slightly larger for the Pacific north-west because its baseline irrigation technology is more heavily defined by the use of either gravity or conventional sprinkler systems. Therefore, technology transitions for the Pacific north-west (for example, transitions from gravity to centre-pivot systems) involve a larger conservation impact than many of the transitions occurring in the mid-plains (for example, transitions from conventional sprinkler or centre-pivot systems to lower-pressure centre-pivot systems). From an environmental policy perspective, then, not only is the level of water use efficiency in agriculture important, but conservation policy design and implementation also need to be regionally specific to maximize environmental benefits. For the Pacific north-west, greater water use efficiency and its environmental benefits are probably more likely with policy that gives greater emphasis to system-based technology changes. However, for the mid-plains, because of its more conserving technology baseline, desired environmental benefits could likely be obtained with an increased conservation policy emphasis given to efficiency gains through improved farm water and chemical management practices. System-based efficiency improvements for the region still remain important for agriculture to meet environmental goals. But farm water/chemical management techniques such as irrigation scheduling based on soil moisture tests, and timely irrigation applications of 
chemicals, are likely to also significantly increase both water and chemical use efficiencies beyond baseline improvements, and thereby significantly improve agriculture's contribution to reducing non-point-source pollution for the region.

\section{Water Policy/Institutional Perspectives}

From an institutional conservation perspective, agricultural water conservation in the west has historically been viewed from a rather narrowly focused quantity perspective (at least within the economics literature), particularly as it applies to surface water supplies. That is, conservation value has been perceived only if it produces additional downstream water quantity. The essence of this argument has been that on-farm water conservation reduces return flows and, therefore, does not increase downstream water quantity. First, such a perspective in most empirical work has ignored the effect on downstream flow quantities associated with both resource and output substitution effects of on-farm water conservation (Schaible et al., 1995; Schaible, 2000). These effects can increase downstream flows due to reduced consumptive use, particularly from surface water sources, and particularly in concert with appropriate institutional changes. Secondly, most empirical work on this topic also erroneously assumes instantaneous return flows. Most aquifers in the west, however, often require many years for full return flow balance. Thirdly, a definition of water conservation designed solely for downstream flow gain ignores a broader social/institutional perspective for agricultural water conservation. In particular, it ignores the water quality benefits of on-farm water conservation associated with reduced non-pointsource pollution, as well as objectives for the sustainability of ecosystem habitats and biodiversity. A broader conservation perspective, in concert with appropriate institutional changes that accompany (and provide incentives for) agricultural water conservation, will affect agricultural water use at both the intensive and extensive margins.

For the mid-plains and Pacific north-west regions, then, because of differences in resource endowments, agroclimatic environments, resource efficiency and production technology baselines and environmental policy goals, acquiring agricultural water conservation beyond baseline expectations implies a need for regionally unique conservation definitions and accompanying institutional changes. For the Pacific north-west, lessening the influence of 'use it or lose it' criteria of beneficial use requirements, promoting broader use of water banking/ trading schemes (including removal of restrictive 'last fill' rules and greater flexibility in the allocation of conserved water supplies) and increasing financial support for Bureau of Reclamation water management for environmental purposes have the potential to significantly influence agricultural water conservation beyond baseline expectations. For the mid-plains states, with agriculture's heavier dependence on groundwater, institutional recognition of a broader role for conservation would improve the water management environment and encourage wider adoption of conservation incentive mechanisms with a direct effect not only on conserving finite resources, but also on reducing polluted return flows and improving groundwater quality. In such areas as the upper Platte Basin (western Nebraska and south-eastern Wyoming), a broader definition of conservation will likely require specialized integration of both surface water and groundwater conservation mechanisms. Here, integrating on-farm conservation with water banking/trading options, along with flexibility 
in the allocation of conserved water supplies, would also likely increase conserved agricultural water beyond baseline expectations.

In the mid-plains states, acceptance of a broader water conservation concept is necessary to move the region's resource policy arena from an over-emphasis on micro-based, intensive margin issues to an integrated policy/institutional perspective that addresses both intensive and extensive margin agricultural water use issues. For the Pacific north-west, the region's heavier dependence on surface water heightens farm concerns with supply security, which tends to promote an institutional status quo. However, the Pacific north-west probably also needs to refocus conservation policy beyond the limiting focus of a quantity-based definition. For the Pacific north-west, broadening the concept of conservation to endogenize watershed-level water quality/ecosystem values could help to integrate conservation policy within its institutional framework. It is likely that a broader on-farm conservation perspective can justifiably serve to provide the necessary compensation to induce broader institutional reforms for the region.

\section{Summary and Conclusions}

It is well recognized that irrigated agriculture contributes to non-point-source pollution problems. It is also recognized that improvements in water and chemical use efficiencies by irrigated agriculture will contribute to resource conservation and water quality policy goals, as well as reducing human health, ecosystem habitat and biodiversity risks associated with agricultural water and chemical use practices.

This paper presents an irrigation technology transition model to evaluate the effect of both locational and time-dependent economic influences on the pace of irrigation technology transitions and improved agricultural water use efficiency for the mid-plains states region. An adaptation of Parks's modified multinomial logit model was estimated, using cross-section/time series data, to simulate expected irrigation technology shares for the mid-plains states out to 2015, by state, for both baseline agri-economic assumptions and two scenarios assuming that baseline economic conditions increase by $10 \%$ and $30 \%$, respectively. Technology simulation results were used to estimate technology response elasticities, and annual agricultural water conservation (by 2015) under both producer-perceived and consumptive use/engineering-based water use rates by technology group. Finally, for additional regional policy insight, results for the mid-plains region were compared with results for the Pacific north-west from Schaible et al. (1991).

Transitions to water-conserving irrigation technology in Kansas and Nebraska have been substantial, particularly for Kansas, much more so than in the Pacific north-west. Under historical annual average economic conditions, transitions to conserving technology in the mid-plains will likely continue at a modest pace. Use of lower-pressure centre-pivot systems could increase (by 2015) by as much as $37 \%$ for Kansas, $23 \%$ for Nebraska, $29 \%$ for South Dakota and $20 \%$ for Wyoming. Technology transitions, however, are relatively crop price inelastic: therefore, an increase in real crop prices can be expected to impact baseline transitions only marginally. Estimates of the impact technology transitions will have on improved aggregate agricultural water use efficiency vary depending upon one's measure of actual agricultural water use rates. Under baseline 
agri-economic assumptions, irrigation technology transitions by 2015 could reduce regional agricultural water use from 0.27 million acre feet to 1.15 million acre feet, effectively increasing regional water use efficiency from about $2.3 \%$ to $9.8 \%$.

Under baseline economic assumptions, then, irrigated agriculture's impact on non-point-source pollution in the mid-plains will likely improve. However, uncertainty as to the potential range of improved water use efficiency suggests that the emphasis of conservation policy could differ depending upon assumed efficiency gains. If improved aggregate water use efficiency is in the range of $2.3 \%$, then to gain greater environmental benefits, resource conservation policy for the region will likely need to more strongly emphasize both irrigation system-based technology changes and improved farm-level water/chemical management practices. If improved aggregate agricultural water use efficiency is in the range of $9.8 \%$, then obtaining the level of desired regional environmental benefit is probably more likely with a more flexible resource conservation policy, that is, policy implementation across the region could vary significantly between emphasizing system-based and/or resource-based management practices.

Comparing mid-plains simulation results with results for the Pacific northwest provides additional insight, for both conservation policy and its institutional setting. Both institutional barriers and resource costs have tended to keep irrigation technology rather stable in the Pacific north-west. For much of the mid-plains, unique water resource characteristics have instilled a heightened awareness of the need for water conservation that serves farm economic and irrigation sustainability goals, as well as farm environmental goals. For both regions, baseline irrigation technology transitions may not be sufficient alone for each of the regions to obtain desired environmental goals. The pace of technical change in irrigated agriculture is unlikely to be the same across regions, even under similar economic conditions. But, given unique regional environmental goals, results here seem to suggest that conservation policy will likely be much more successful if it takes into account regional resource, institutional and agri-economic differences, as well as the unique transitional state of regional agricultural production technology.

Finally, a downstream flow gain, quantity-based definition of agricultural water conservation is a narrowly focused conservation perspective. A more broadly defined, social/institutional conservation perspective, one that integrates on-farm water conservation incentive policy with regionally unique innovations in water institutions, will likely make a more significant contribution to human health and environmental policy goals, as well as to regional agricultural sustainability. On-farm water conservation policy could likely serve to provide the necessary compensation to induce broader institutional reforms that effect both intensive and extensive margin agricultural water use efficiency for a region.

\section{Acknowledgement}

The authors are with the Resource Economics Division, Economic Research Service, USDA, Washington, DC. The views expressed in this paper are the authors' and do not necessarily represent those of the USDA.

\section{Note}

1. Metric conversion factors are 1 hectare $=2.4710437$ acres or alternatively, 1 acre $=0.4046873$ hectare. 


\section{References}

Amemiya, T. \& Nold, F. (1975) A modified logit model, Review of Economics and Statistics, 57, pp. 255-257.

Barbash, J.E. \& Resek, E.A. (1995) Pesticides in Ground Water: Current Understanding of Distribution and Major Influences (Washington, DC, USGS, US Department of Interior).

Bricker, L.B., Clement, C.G., Pirhalla D.E., Orlando, S.P. \& Farrow, D.R.G. (1999) National Estuarine Eutrophication Assessment: Effects of Nutrient Enrichment in the Nation's Estuarines (Silver Spring, MD, National Ocean Service, Special Projects Office \& National Centers for Coastal Ocean Science National Oceanic Atmospheric Administration).

Caswell, M. \& Zilberman, D. (1985) The choices of irrigation technologies in California, American Journal of Agricultural Economics, 67, pp. 224-234.

Caswell, M. \& Zilberman, D. (1986) The effects of well depth and land quality on the choice of irrigation technology, American Journal of Agricultural Economics, 68, pp. 798-811.

Chan, M.W.L. (1981) A Markovian approach to the study of the Canadian cattle industry, Review of Economics and Statistics, 63, pp. 107-116.

Department of Energy (DOE) $(1992,1993)$ State Energy Price and Expenditure Reports/Monthly Energy Review (Washington, DC, Energy Information Agency, Department of Energy (DOE)), available at: www.eia.doe.gov.

Dugan, J.T. \& Cox, D.A. (1994) Water-level Changes in the High Plains Aquifer: Predevelopment to 1993, Water-resource Investigations Report 94-4157 (Lincoln, NE, USGS).

Fischman, R.L. (1992) Bio-diversity and ecological management, Environmental Law, 22, pp. 435-458.

Farm Service Agency (FSA) (1972-95) Annual data obtained via personal communication with Farm Service Agency (FSA), USDA, Washington, DC.

Green, G.P. \& Sunding, D.L. (1997) Land allocation, soil quality, and the demand for irrigation technology, Journal of Agricultural and Resource Economics, 22, pp. 367-375.

Green, G., Sunding, D., Zilberman, D. \& Parker, D. (1996) Explaining irrigation technology choices: a micro-parameter approach, American Journal of Agricultural Economics, 78, pp. 1064-1072.

Lichtenberg, E. (1989) Land quality, irrigation development, and cropping patterns in the northern High Plains, American Journal of Agricultural Economics, 71, pp. 187-194.

McFadden, D. (1974) Conditional logit analysis of qualitative choice behavior, in: P. Zarembka (Ed.) Frontiers in Econometrics (New York, Academic Press).

McFadden, D. (1976) Quantal choice analysis: a survey, Annals of Economic and Social Measurement, 5, pp. 363-390.

McFadden, D. (1981) Econometric models of probabilistic choice, in: C. F. Manski \& D. McFadden (Eds) Structural Analysis of Discrete Data with Econometric Applications (Cambridge, MA, MIT Press).

Mueller, D.K., Hamilton, P.A., Helsel, D.R., Hitt, K.J. \& Ruddy, B.C. (1995) Nutrients in Ground Water and Surface Water of the United States: An Analysis of Data through 1992, Water Resources Investigations Report 95-4031 (Washington, DC, USGS, US Department of Interior).

NASS (1972-95a) Agricultural Prices (Washington, DC, USDA).

NASS (1972-95b) Agricultural Production (Washington, DC, USDA).

NASS (1972-95c) Annual Price Summary (Washington, DC, USDA).

NASS (1999a) 1997 Census of Agriculture: State Data (Washington, DC, USDA) (www.nass.usda.gov).

NASS (1999b) Farm and Ranch Irrigation Survey (1998), Volume 3, Special Studies, Part 1 (Washington, DC, USDA) (www.nass.usda.gov).

Negri, D.H. \& Brooks, D.H. (1990) Determinants of irrigation technology choice, Western Journal of Agricultural Economics, 15, pp. 213-223.

NRC (1992) Restoration of Aquatic Ecosystems: Science,Technology, and Public Policy (Washington, DC, National Academy Press).

NRC (1996) Review of the Department of the Interior's National Irrigation Water Quality Program: Planning and Remediation, Committee on Planning and Remediation for Irrigation-induced Water Quality Problems (Washington, DC, Water Science and Technology Board, NRC).

NRCS (1996) America's Private Land: A Geography of Hope (Washington, DC, USDA).

NRCS (1997) Water Quality and Agriculture: Status, Conditions, and Trends, Working Paper 16 (Washington, DC, USDA).

Parks, R.W. (1967) Efficient estimation of a system of regression equations when disturbances are both serially and contemporaneously correlated, Journal of American Statistical Association, 62, pp. 500-509.

Parks, R.W. (1980) On the estimation of multinomial logit models from relative frequency data, Journal of Econometrics, 13, pp. 293-303. 
Pudney, S. (1989) Modelling Individual Choice: The Econometrics of Corners, Kinks and Holes (New York, Basil Blackwell).

Schaible, G.D. (2000) Economic and conservation tradeoffs of regulatory vs. incentive-based water policy in the Pacific Northwest, International Journal of Water Resources Development, 16(2), pp. 221238.

Schaible, G.D., Kim, C.S. \& Whittlesey, N.K. (1991) Water conservation potential from irrigation technology transitions in the Pacific Northwest, Western Journal of Agricultural Economics, 16, pp. 194-206.

Schaible, G.D., Gollehon, N.R., Kramer, M.S., Aillery, M.P. \& Moore, M.R. (1995) Economic Analysis of Selected Water Policy Options for the Pacific Northwest, Agricultural Economic Report 720 (Washington, DC, Economic Research Service, USDA).

Shrestha, R.B. \& Gopalakrishnan, C. (1993) Adoption and diffusion of drip irrigation technology: an econometric analysis, Economic Development and Cultural Change, 41(2), pp. 407-418.

Sloggett, G. (1985) Energy and US Agriculture: Irrigation Pumping, 1974-83, Agricultural Economic Report 545 (Washington, DC, Economic Research Service, USDA).

Soil Conservation Service, USDA (1976) Crop Consumptive Irrigation Requirements and Irrigation Efficiency Coefficients for the United States (Washington, DC, USDA).

Solley, W.B., Pierce, R.R. \& Perlman, H.A. (1998) Estimated Use of Water in the United States in 1995, Circular 1200 (Denver, CO, USGS, US Department of Interior).

USDA (2001) Food and Agricultural Policy: Taking Stock for the New Century (Washington, DC, USDA).

USEPA (1998) The Quality of Our Nation's Water: 1996 (Washington, DC, Office of Water, USEPA) (www.epa.gov/305b).

USEPA (1999) Safe Drinking Water Act, Section 1429 Ground Water Report to Congress, EPA-816-R-99016 (Washington, DC, Office of Water, USEPA).

USFWS (1992) An Overview of Irrigation Drainage Technologies, Impacts on Fish and Wildife Resources and Management Options (Washington, DC, USEPA).

USGS (1999) The Quality of Our Nation's Waters: Nutrients and Pesticides, US Geological Circular 1225 (Washington, DC, US Department of Interior) (www.water.usgs.gov/pubs/circ/circ1225).

Zellner, A. \& Lee, T.H. (1965) Joint estimation of relationships involving discrete random variables, Econometrica, 33, pp. 382-394. 